Scientia Marina 71(1)

March 2007, 95-100, Barcelona (Spain)

ISSN: 0214-8358

\title{
The occurrence of Natsushima bifurcata (Polychaeta: Nautiliniellidae) in Acharax hosts from mud volcanoes in the Gulf of Cadiz (south Iberian and north Moroccan Margins)
}

\author{
ASCENSÃO RAVARA, MARINA R. CUNHA and CLARA F. RODRIGUES \\ Centro de Estudos do Ambiente e do Mar, Departamento de Biologia, Universidade de Aveiro, \\ Campus de Santiago, 3810-193 Aveiro, Portugal. E-mail: aravara@bio.ua.pt
}

\begin{abstract}
SUMMARY: Fifteen specimens of nautiliniellid polychaetes were found in the mantle cavity of bivalves of the genus Acharax (Solemyidae) collected in several mud volcanoes from the Gulf of Cadiz. They were identified as Natsushima bifurcata Miura and Laubier (1990), a species previously known only from Sagami Bay (Japan). The morphological comparison of these specimens with the holotype suggests that they belong to the same morphological species, although further studies should consider whether they could be genetically different. The ecology of the species is discussed in relation to the available information on the family. The occurrence of Natsushima bifurcata in the Gulf of Cadiz is the first record of the species in the North Atlantic.

Keywords: Natsushima bifurcata, Gulf of Cadiz, mud volcanoes, Polychaeta.

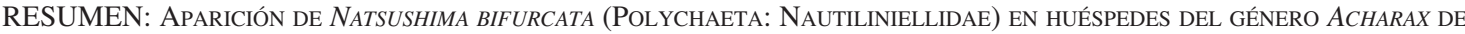

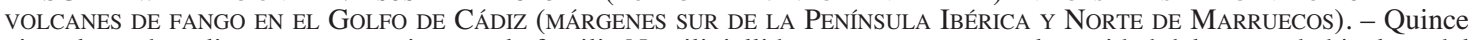
ejemplares de poliquetos pertenecientes a la familia Nautiliniellidae se encontraron en la cavidad del manto de bivalvos del género Acharax (Solemyidae) procedentes de varios volcanes de fango del Golfo de Cádiz. Los ejemplares se identificaron como Natsushima bifurcata Miura y Laubier (1990), una especie citada únicamente de la bahía de Sagami (Japón). El presente trabajo analiza la morfología de los ejemplares de Cádiz en comparación con la del holotipo y sugiere que ambas poblaciones pertenecen al mismo morfotipo, sin que no por ello se pueda descartar la existencia de diferencias en el componente genético. Asímismo, se discuten aspectos ecológicos basados en la información disponible sobre la familia. La aparición de Natsushima bifurcata en el Golfo de Cádiz representa la primera cita para el Atlántico Norte.
\end{abstract}

Palabras clave: Natsushima bifurcata, Golfo de Cádiz, volcanes de fango, Polychaeta.

\section{INTRODUCTION}

Miura and Laubier (1990) used the names Nautiliniellidae and Nautiliniella to replace the homonyms Nautilinidae and Nautilina (Miura and Laubier, 1989), because the genus name had already been occupied by a cephalopod mollusc. At present, this small family of uncommon polychaetes includes fifteen species ascribed to eleven genera found in the mantle cavity of deep-sea bivalve molluscs of the families Solemyidae, Mytilidae, Thyasiridae and Vesicomyidae (Miura and Hashimoto, 1996; Dreyer et al., 2004). Nautiliniellids are mainly restricted to Pacific hydrothermal vents and cold seeps (Blake, 1993; Miura and Hashimoto, 1993, 1996; Miura and Laubier, 1989, 1990; Miura and Ohta, 1991). Up to now, only two species, Petrecca thyasira Blake, 1990, found in the gill filaments of Thyasira insignis 
specimens from the Laurentian Fan, and Vesicomyicola trifurcatus Dreyer, Miura and Van Dover, 2004, found in the mantle cavity of the vesicomyid clams from the Blake Ridge cold seep off the coast of South Carolina, are known to occur in the Atlantic Ocean (Blake, 1990; Dreyer et al., 2004). Nautiliniellids are commonly quoted as commensals or parasites (Blake, 1990; Miura and Laubier, 1990) but the nature of the association between the polychaetes and their bivalve hosts is still unclear.

Communities of benthic animals associated with cold seeps are known from several locations on active and passive continental margins of the Pacific and have recently been discovered also in the Atlantic Ocean (Olu-Le Roy et al., 2004). The occurrence of mud volcanism, cold seepage, hydrocarbon venting and gas hydrates in the Gulf of Cadiz has been intensively investigated since 1996 (e.g. Pinheiro et al., 2003; Van Rensbergen et al., 2005). Within the framework of the UNESCO/IOC Training Through Research Programme, seven research cruises were conducted for this specific purpose: TTR9 (1999), TTR10 (2000), TTR11 (2001), TTR12 (2002), TTR14 (2004), TTR15 (2005) and TTR16 (2006).

The solemyid bivalve Acharax sp. is one of the most common species of the chemoauthosynthesisbased assemblage of the mud volcanoes from the Gulf of Cadiz (Rodrigues and Cunha, 2005). In three of these mud volcanoes some of the bivalve specimens were found to host in their mantle cavity nautiliniellid polychaetes identified as Natsushima bifurcata Miura and Laubier (1990), previously known only from Sagami Bay (Japan). These recently collected specimens verify the original concept of the species and provide the first record of $N$. bifurcata for the North Atlantic.

\section{MATERIAL AND METHODS}

\section{Study site}

The Gulf of Cadiz is located at the crossroads of the European and African Atlantic margins and the Mediterranean. The compression between the Eurasian and African tectonic plates creates an interesting geophysical template shaped by volcanic activity and by the interaction between the topography and the circulation of the Atlantic and Mediterranean Ocean Waters. Geologically, the set- ting of the Gulf of Cadiz is extremely complex and still under debate but one of the most important structures is a large olistostrome complex emplaced in an accretionary wedge-type environment. (Sartori et al., 1994; Maldonado et al., 1999; Gutscher et al., 2002). Since the discovery of the first mud volcano in 1999, about 30 other sites at depths ranging from 200 to $4000 \mathrm{~m}$, with varying degrees of hydrocarbon-rich gas seepage activity, have been located and sampled (Pinheiro et al., 2003; Van Rensbergen et al., 2005).

\section{Collection of samples}

Samples were collected during the TTR cruises (Training Through Research Programme, IOCUNESCO) onboard the RV Prof. Logachev. A TVassisted grab was used to locate interesting sampling sites in the target mud volcanoes. Whenever Acharax specimens were collected, usually from sites within the crater of active mud volcanoes, they were opened and examined onboard for the presence of nautiliniellid polychaetes. The biological material was preserved in 70 or $96 \%$ ethanol (the latter will be used for future molecular analysis).

\section{SYSTEMATICS}

Family NAUTiLiniellidae Miura and Laubier, 1989 Natsushima Miura and Laubier, 1990

Natsushima bifurcata Miura and Laubier, 1990 (Fig. 1)

Natsushima bifurcata Miura and Laubier, 1990: 322-323, Fig. 2 af; Miura and Hashimoto, 1996: 265-266.

Type material. Holotype (NSMT-Pol. H-294), complete; Pacific Ocean, off Hatsushima, Sagami Bay, 3400.0'N, $139^{\circ} 13.8^{\prime}$ 'E, 1170 m, 19 November 1987, deep-sea submersible "Shinkai-2000" Dive 315 ; collected from the mantle cavity of Acharax sp.

Other material. 1 complete specimen (USNM 172135); Pacific Ocean, off Hatsushima, Sagami Bay, 34'58.12'N, 139³1.24'E, 1114 m, 17 May 1989, Dolphin 3000, collected from the mantle cavity of Acharax johnsoni. 3 complete specimens (DBUA 00711), Atlantic Ocean, Gulf of Cadiz, Jesuz Baraza mud volcano, $35^{\circ} 35.439^{\prime} \mathrm{N}, 7^{\circ} 12.264^{\prime} \mathrm{W}, 1105 \mathrm{~m}$, TTR12 station AT391GR, 9 July 2002; 1 damaged specimen (DBUA 00765), same locality, Yuma mud volcano, $35^{\circ} 24.973^{\prime} \mathrm{N}, 7^{\circ} 05.461^{\prime} \mathrm{W}, 960 \mathrm{~m}$, TTR14 station AT524GR, 2 August 2004; 4 complete specimens (DBUA 00791-01), same locality, same mud volcano, 35²5.820'N, $7^{\circ} 06.330^{\prime} \mathrm{W}, 1030 \mathrm{~m}$, TTR16 station AT604GR, 29 May 2006; 4 complete and 1 incomplete specimens (DBUA 00791-02), same locality, same mud volcano, $35^{\circ} 25.046^{\prime} \mathrm{N}, 7^{\circ} 05.450^{\prime} \mathrm{W}, 975 \mathrm{~m}$, TTR16, AT605GR, 29 May 2006; 2 complete specimens (DBUA 00791-03) same locality, Ginsburg mud volcano, $35^{\circ} 22.677^{\prime} \mathrm{N}$, 704.979’W, 920 m, TTR16 station AT607GR, 29 May 2006. All 


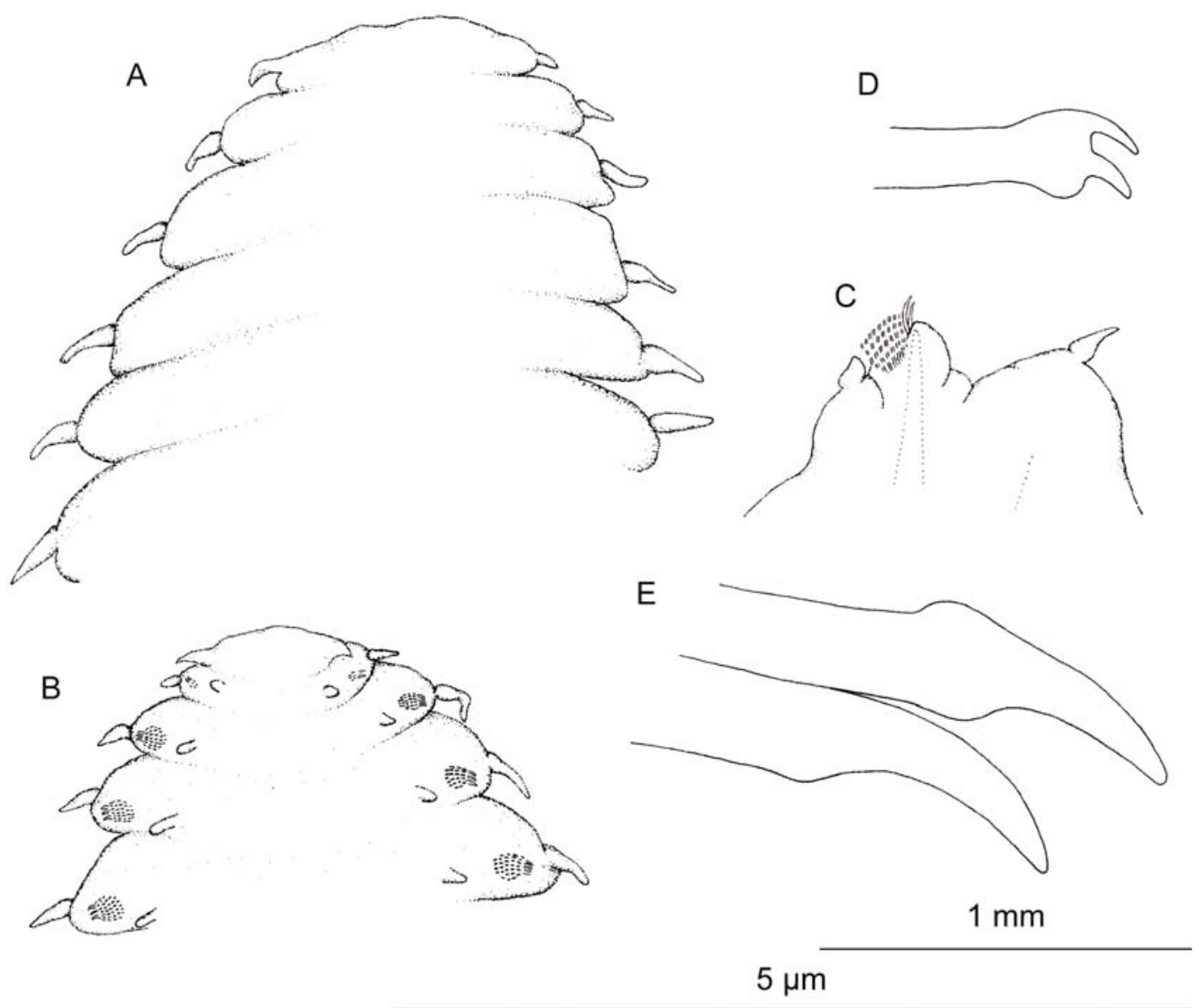

FIG. 1. - Natsushima bifurcata DBUA 00711: A, anterior region, dorsal view; B, anterior region, ventral view; C, 29 $9^{\text {th }}$ parapode, anteroposterior view; $\mathrm{D}$, neuropodial bifurcate setae; $\mathrm{E}$, neuropodial hooks.

specimens from Gulf of Cadiz were collected onboard the RV Prof. Logachev with a TV-assisted grab, and were found inside the mantle cavity of Acharax sp.

Diagnosis. Body vermiform, flattened ventrally and arched dorsally, with fairly uniform width throughout. Short prostomium, much wider than long, slightly incised anteriorly, with only a pair of lateral antennae and without eyes. Tentacular segment partially fused to prostomium, with dorsal and ventral cirri, neuroaciculae, and few neurosetae. Parapodia sub-biramous, with well-developed dorsal and ventral cirri. Notopodia short conical, similar throughout the body, with slender notoacicula and without setae. Neuropodia cylindrical, with neuroacicula and numerous setae of two kinds - up to 4 (usually 3 ) stout slightly curved hooks placed more dorsally and more than 100 smaller bifurcate setae placed ventrally.

Supplementary description. Largest specimens measure $17 \mathrm{~mm}$ in length and $\sim 3 \mathrm{~mm}$ in width, for 72 setigers. Colour in life pink, and after preservation white.
Remarks. The original description of the holotype mentions that the specimens were found inside Solemya sp. bivalves (Miura and Laubier, 1989: 322) but the identification of the bivalve was corrected to Acharax johnsoni in a subsequent work by Ohta (1990, cited in Miura and Hashimoto, 1996: 266).

The specimens from the Gulf of Cadiz are larger than the ones from the type locality (Table 1) and in some neuropodia (Fig. 2) there are 4 hooks (up to 3 in the original description). The diagnosis of the species was updated accordingly.

Ecology. The host bivalve, Acharax sp. has a wide distribution in the Gulf of Cadiz: it has been recorded from ten mud volcanoes in the Moroccan and Portuguese margins at depths varying from 358 to $3902 \mathrm{~m}$. The nautiliniellid polychaetes were found in the mantle cavity, near the gill filaments, of Acharax specimens collected from the Jesús Baraza, Yuma and Ginsburg mud volcanoes, all located in the Western Moroccan field within a bathymetric range restricted to 920 and $1105 \mathrm{~m}$ (Fig. 3). At these 
TABLE 1. - Measurements of the specimens examined from the Gulf of Cadiz (GoC) and Sagami Bay (SB). JB, Jesús Baraza mud volcano; Y, Yuma mud volcano; G, Ginsburg mud volcano. Width includes parapodia.

\begin{tabular}{lcccc}
\hline Specimens & $N^{\circ}$ of setigers & $\begin{array}{c}\text { Total length } \\
(\mathrm{mm})\end{array}$ & $\begin{array}{c}\text { Width } \\
(\mathrm{mm})\end{array}$ & $\begin{array}{c}\text { Length } \\
\text { of dorsal } \\
\text { cirri(mm) }\end{array}$ \\
\hline GoC-JB1 & 72 & 17.0 & 3.0 & 0.15 \\
GoC-JB2 & 67 & 17.0 & 3.0 & 0.15 \\
GoC-JB3 & 75 & 12.0 & 2.1 & 0.15 \\
GoC-Y1 & $>60$ & $\sim 9.6$ & 1.4 & 0.15 \\
GoC-Y2 & 71 & 8.2 & 1.6 & 0.14 \\
GoC-Y3 & 99 & 18.0 & 2.1 & 0.17 \\
GoC-Y4 & 79 & 16.0 & 1.8 & 0.17 \\
GoC-Y5 & 40 & 9.3 & 1.6 & 0.17 \\
GoC-Y6 & 50 & 8.6 & 1.4 & 0.17 \\
GoC-Y7 & 72 & 13.9 & 1.4 & 0.12 \\
GoC-Y8 & 71 & 17.0 & 2.1 & 0.17 \\
GoC-Y9 & 55 & 8.8 & 1.4 & 0.15 \\
GoC-Y10 & 48 & 7.7 & 1.4 & 0.15 \\
GoC-G1 & 80 & 14.9 & 1.3 & 0.12 \\
GoC-G2 & 88 & 21.4 & 3.2 & 0.17 \\
SB & 70 & 15.0 & 1.5 & 0.14 \\
SB-holotype & 47 & 5.0 & 0.6 & 0.07 \\
\end{tabular}

three mud volcanoes, observed infestation rates varied from 12.5 to $75 \%$ and the number of nautiliniellid individuals found in each bivalve varied from 1 to 3 (Table 2). The infested Acharax specimens measured between 3.2 and $6.9 \mathrm{~cm}$ (total length).

Distribution. East Pacific, Sagami Bay: Hatsushima and Okino-yama cold seeps, 1114-1170 m, inside the mantle cavity of Acharax johnsoni Dall, 1891. North Atlantic, Gulf of Cadiz: Jesús Baraza, Yuma and Ginsburg mud volcanoes, 920-1105 m, inside the mantle cavity of an undetermined Acharax species.

\section{DISCUSSION}

The genus Natsushima comprises at present two described species, $N$. bifurcata Miura and Laubier, 1990 and N. graciliceps Miura and Hashimoto, 1996. The two species differ by the presence of respectively short conical and elongated notopodia in the middle segments, by the presence of a fine embedded notoacicula in the former and by the different size of dorsal and ventral cirri, which are smaller in the latter.

Both Sagami Bay specimens of $N$. bifurcata occur in cold seeps associated with Solemyid bivalves at depths of around $1000 \mathrm{~m}$, and the specimens recently collected in the Gulf of Cadiz corroborate this information. In fact, it is noteworthy that despite the wider bathymetric range of Acharax in the Gulf of Cadiz (358-3902 m), up to now only the populations from the mud volcanoes of the Western Moroccan field, located at depths of 920-1105 m, were found to be infested by nautilin-

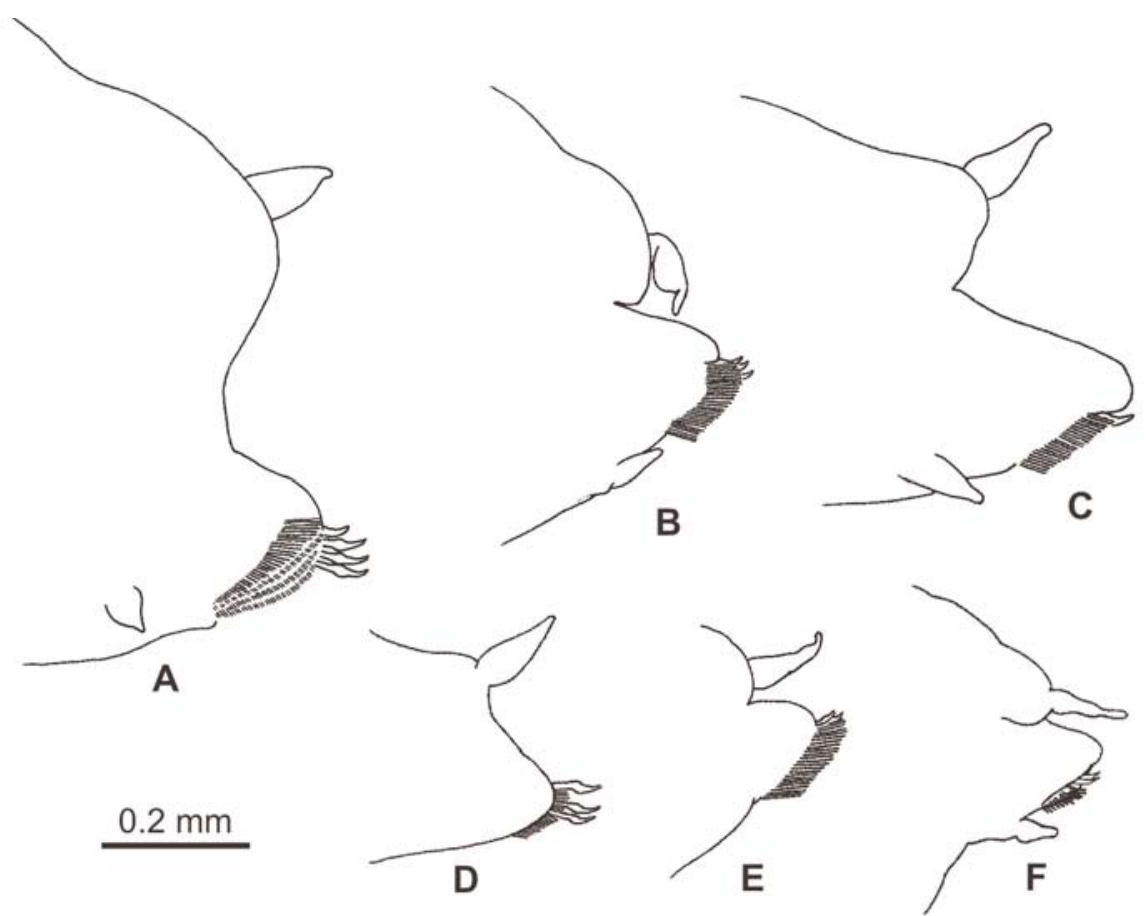

FIG. 2. - Median parapodes: specimens A, B and C collected in the Gulf of Cadiz, in July 2002, DBUA 00711; specimen D from Sagami Bay, USNM 172135; specimen E collected in Gulf of Cadiz, in August 2004, DBUA 00765; Hototype F, from Sagami Bay, NSMT-Pol. H-294, re-illustrated from Miura and Laubier (1990). 
TABLE 2. - Infestation rates; number of specimens of Natsushima bifurcata and Acharax sp. collected in each mud volcano (Number of N. bifurcata in each host Acharax in brackets).

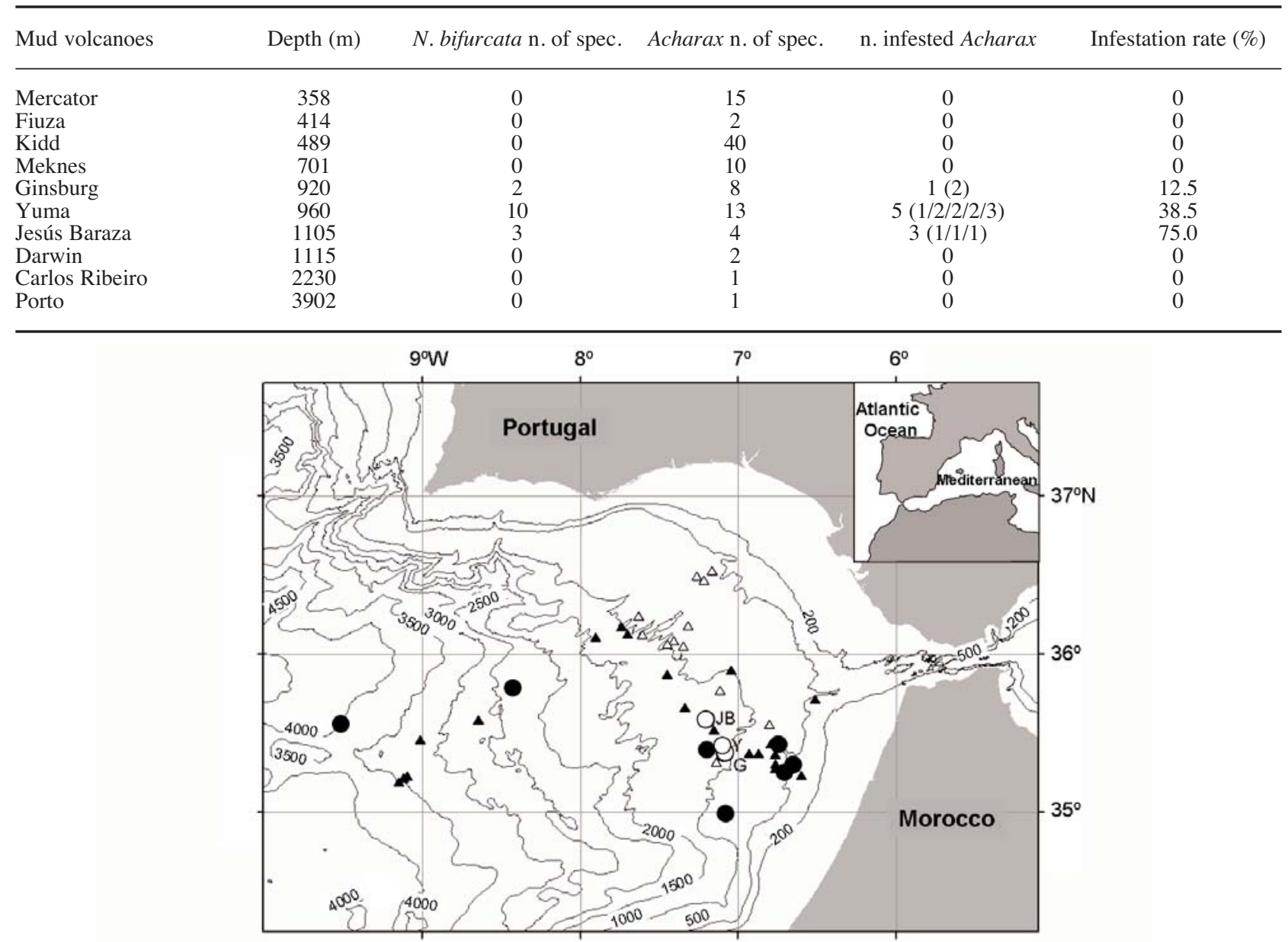

FIG. 3. - Map of the study area: full triangles - sampled sites; empty triangles - other known mud volcanoes; full circles - sites with Acharax populations; empty circles - sites with infested Acharax populations. JB, Y and G - Jesús Baraza, Yuma and Ginsburg mud volcanoes.

iellids (up to $75 \%$ infestation rate). The majority (69.8\%) of the 96 Acharax specimens were collected at the four shallowest mud volcanoes (358-701 $\mathrm{m})$ but none of these specimens were infested. The populations from the three deepest mud volcanoes (1115-3902 m) were also not infested but the number of specimens collected was much lower (only $4.2 \%$ of the total).

According to Neulinger et al. (2006), Acharax species differentiation based on shell morphology is likely to underestimate true species diversity within this taxon. A phylogenetic study based on some Acharax specimens from localities of the Pacific and Indian oceans (Aleutian Trench, off Oregon, Costa Rica, and Peru margins, and off Makran, and Java) resulted in two clusters that group populations located far apart (Makran, Oregon, and Peru in one cluster and Java, Aleutian Trench and Costa Rica in the other). These authors propose that the specimens are representatives of at least 2 different species and do not all belong to $A$. johnsoni, as assumed previously.

These results emphasize the need for further morphological and probably also genetic studies to solve taxonomic affinities within Acharax populations. Until then, we cannot assume that the Gulf of Cadiz and Sagami Bay specimens belong to the same species but nor can we discard this possibility. The same applies to the Natsushima specimens. We could not find morphological evidence to support the establishment of a new species. The comparison with the holotype only revealed differences in the proportions of the specimens (Fig. 2; Table 1). The largest specimens from the Gulf of Cadiz are 2 to 3 times larger than the holotype, the setigers are broader and the parapodia, including cirri, are thicker. The holotype seems to have proportionally longer and thinner dorsal cirri and antennae, and it is 
also smaller. This different appearance is due to the more corpulent body of the larger specimens, resulting in proportionally broader and shorter cirri. In support of this, medium-sized specimens, such as the DBUA 00765 from the Gulf of Cadiz, and the USNM 172135 from Sagami Bay, show "intermediate" morphological features between the larger, more corpulent specimens and the holotype. It is possible that $N$. bifurcata from Sagami Bay and the specimens from Gulf of Cadiz are cryptic species but this question can only be answered with more knowledge on reproductive patterns and by the analysis of DNA sequences. As the preservation of the Japanese specimens does not allow DNA analysis, we must consider that both the Cadiz and the Sagami specimens belong to the same morphological species.

There are several cases of specimens from distant locations of other deep sea species that are ascribed to the same morphological species. An example is the commensal polychaete Branchipolynoe seepensis Pettibone, 1986 that was recorded in several bivalve host species both in the Gulf of Mexico and in the mid-Atlantic Ridge. In this case, subsequent studies carried out by Chevaldonné et al. (1998) determined the genetic divergence for the COI and 16S rDNA genes and showed that the Atlantic and Pacific populations should be considered as two isolated phylogenetic species.

\section{ACKNOWLEDGEMENTS}

Thanks are due to the co-chief-scientists Luís Pinheiro (Departamento de Geociências, Universidade de Aveiro) and Michael Ivanov (Moscow State University) for the invitation to participate in the TTR cruises (Training Through Research Programme, IOC-UNESCO). We also gratefully acknowledge the critical reading of this paper by Tomoyuki Miura. This research was partially supported by the HERMES project, EC contract GOCE-CT-2005-511234, funded by the European Commission's Sixth Framework Programme under the priority "Sustainable Development, Global Change and Ecosystems".

\section{REFERENCES}

Blake, J.A. - 1990. A new genus and species of Polychaeta commensal with a deep-sea thyasirid clam. Proc. Biol. Soc. Wash., 103: 681-686.

Blake, J.A.-1993. New genera and species of deep-sea polychaetes of the family Nautiliniellidae from the Gulf of Mexico and the Eastern Pacific. Proc. Biol. Soc. Wash., 106: 147-157.

Chevaldonné, P., D. Jollivet, R.A. Feldman, D. Desbruyères, R.A. Lutz and R.C. Vrijenhoek. - 1998. Commensal scale-worms of the genus Branchipolynoe (Polychaeta: Polynoidae) at deep-sea hydrothermal vents and cold seeps. Cah. Biol. Mar., 39(3-4): 347-350.

Dreyer, J., T. Miura and C.L. Van Dover. - 2004. Vesicomyicola trifurcatus, a new genus and species of commensal polychaete (Annelida : Polychaeta : Nautiliniellidae) found in deep-sea clams from the Blake Ridge cold seep. Proc. Biol. Soc. Wash., 117(1): 106-113.

Gutscher, M.A., J. Malod, J.P. Rehault, I. Contrucci, F Klingelhoefer, L. Mendes-Victor and W. Spakman. - 2002. Evidence for active subduction beneath Gibraltar. Geology, 30(12): 1071-1074.

Maldonado, A., L. Somoza and L. Pallarés. - 1999. The Betic orogen and the Iberian-African boundary in the Gulf of Cadiz: geological evolution (central North Atlantic). Mar. Geol., 155: 9-43.

Miura, T. and J. Hashimoto. - 1993. Mytilidiphila, a new genus of nautiliniellid polychaetes living in the mantle cavity of deepsea mytilid bivalves collected from the Okinawa Trough. Zool. Sci., 10: 169-174

Miura, T. and J. Hashimoto. - 1996. Nautiliniellid polychaetes living in the mantle cavity of bivalve molluscs from cold seeps and hydrothermal vents around Japan. Publ. Seto Mar. Biol. Lab., 37(3-6): 257-274.

Miura, T. and L. Laubier. - 1989. Nautilina calyptogenicola, a new genus and species of parasitic polychaete on a vesicomyd bivalve from the Japan trench, representative of a new family Nautilinidae. Zool. Sci., 6: 387-390.

Miura, T. and L. Laubier. - 1990. Nautiliniellid polychaetes collected from the Hatsushima cold-seep site in Sagami Bay, with descriptions of new genera and species. Zool. Sci., 7: 319-325.

Miura, T. and S. Ohta. -1991 . Two polychaete species from the deep-sea hydrothermal vent in the Middle Okinawa Trough. Zool. Sci. 8: 383-387.

Neulinger, S.C., H. Sahling, J. Süling and J.F. Imhoff. - 2006. Presence of two phylogenetically distinct groups in the deepsea mussel Acharax (Mollusca: Bivalvia: Solemyidae). Mar. Ecol. Prog. Ser. 312: 161-168.

Olu-Le Roy, K., M. Sibuet, A. Fiala-Médioni, S. Gofas, C. Salas, A. Mariotti, J.-P. Foucher and J. Woodside. - 2004. Cold seep communities in the deep eastern Mediterranean Sea: composition, symbiosis and spatial distribution on mud volcanoes. Deep-Sea Res. I, 51: 1915-1936.

Pinheiro, L.M., M.K. Ivanov, A. Sautkin, G. Akhmanov, V.H. Magalhães, A. Volkonskaya, J.H. Monteiro, L. Somoza, J. Gardner, N. Hamouni and M.R. Cunha.-2003. Mud volcanism in the Gulf of Cadiz: results from the TTR-10 cruise. Mar. Geol., 195: 131-151.

Rodrigues, C.F. and M.R. Cunha. - 2005. Common chemosynthetic species in the Gulf of Cadiz: updated spatial distribution. IOC Workshop Report, 197: 26-28.

Sartori, R., L. Torelli, N. Zitellini, D. Peis and E. Lodolo - 1994. Eastern segment of the Azores-Gibraltar line (central-eastern Atlantic): an oceanic plate boundary with diffuse compressional deformation. Geology, 22: 555-558.

Van Rensbergen, P., D. Depreiter, B. Pannemans, G. Moerkerke, D. Van Rooij, B. Marsset, G. Akhmanov, V. Blinova, M. Ivanov, M. Rachidi, V. Magalhães, L. Pinheiro, M. Cunha and J.-P. Henriet. - 2005. The El Arraiche mud volcano field at the Moroccan Atlantic slope, Gulf of Cadiz. Mar. Geol., 219: 1-17.

Scient. ed.: D. Martin.

Received March 31, 2006. Accepted October 13, 2006.

Published online February 8, 2007. 